\title{
RAINFALL EROSIVITY IN SOUTHEASTERN NIGERIA ${ }^{*}$ Ezemonye, M. N. ${ }^{1}$ and Emeribe, C. N. ${ }^{2}$ DOI:http://dx.doi.org/10.4314/ejesm.v5i2.1
}

Received 13 ${ }^{\text {th }}$ October 2011; accepted 28 ${ }^{\text {th }}$ February 2012

\begin{abstract}
In developing land management plans to minimize erosion problem, it is imperative to provide quantitative information on aggressiveness of storms for identifying areas in the landscape which are sensitive to disturbances. The study established that rainfall erosivity $(R)$ indices over Southeastern Nigeria range from very low to very high erosivity. Periods of very low erosivity coincided with the dry season months in the region while the very high $R$ coincided with the rainy season peak periods (June-September). Calabar Owerri and Port-Harcourt recorded the highest erosive storms/ more months of very high erosivity index. The deterministic relationship between kinetic energy of rains and erosivity pattern observed for the different stations showed that erosive rains contribute significantly to detachment of soil materials in the study area. The need for proper land use management and maintenance of surface vegetal covers cannot be overemphasized with increased weather variability. Monitoring of hydrologic regime and climate -related factors in the region as well as defining areas most vulnerable to erosion would help in erosion disaster management.
\end{abstract}

Keywords: soil erosion, erosivity Index, land use management and rainfall

\section{Introduction}

The potential for erosion is based on many factors including soil type, slope, and the energy or force of precipitation expected during the period of surface disturbance. Rainfall erosivity is a term that is used to describe the potential for soil to wash off disturbed, de-vegetated areas and into surface waters of the state during storms The identification of some climatic inputs for rainfall erosivity modeling and scenarios at regional scales is important for understanding the rainfall and storms characteristics and their potential impact on local agricultural and ecological systems (Diodato and Bellocchi, 2010).

Under particular environmental conditions, rainfall is the main factor driving soil degradation because it can erode soils and nutrients by the force of raindrops, surface and subsurface runoff (Zachar, 1982; Lal, 2001). In the tropics, studies have shown that the most important factor that is of direct relevance to erosion studies is rainfall, while other factors include topography, soil, geology and land management techniques (Young, 1972; Olson, 1982; FAO, 1987; Jeje and Agu, 1990).

\footnotetext{
${ }^{1}$ Department of Geography and Regional Planning, University of Benin, Benin City, Nigeria

${ }^{2}$ Environmental/Pollution Remediation Unit of the National Centre for Energy and Environment, Energy Commission of Nigeria, University of Benin, Benin city Corresponding author email: ezemonyemary@yahoo.com
}

Several attributes of rainfall bear direct relevance to the incidence of erosion in the human landscape. Such attributes include: rainfall intensity, drop size, duration of fall, annual total amount, and frequency of fall, kinetic energy and terminal velocity, among others (Ologe, 1972; Oyegun, 1980).These rainfall characteristics have been observed by Elwell and Stocking (1974) to have the ability to loosen up soil structures and consequently remove earth materials from different surfaces. Soil erosion is basically initiated by detachment, which is mainly controlled by shear forces of the falling raindrops, and represented by rainfall erosivity factor (Petkovesk and Mikos, 2004; Asadi et al., 2008). The impact energy of raindrop sets into motion the destruction of aggregates while runoff water provides for the transport of detached particles (Roose, 1975) This results in degradation of ecosystem function (Ludwig and Tgway, 2000; Ludwig et al., 2006) decreased productivity and sustainability of agriculture (Diamond, 2005), and displacement of human populations (Opie, 2000).

Rainfall aggressiveness has always been a prominent environmental threat in the course of 
human history, especially affecting the agricultural sector. However, studies on soil erosion only started in the first decades of the 20th century and have increased in number and variety since then, especially targeting at isolating the role of different natural factors on soil erosion (Angulo-Martinez et al., 2009). In recent years, the analysis of rainfall extremes and aggressiveness has attracted the attention of researchers across the world (Garcia-Oliva et al., 1995; Sauerborn et al., 1999; Easterling et al., 2000; Nearing et al., 2004; Schutt et al., 2007). It has been with the advent of mathematical models of soil erosion that rainfall aggressiveness, defined under the name of "rainfall erosivity ( $\mathrm{R}$ index)", has been systematically analyzed

The rainfall erosivity factor is used to quantify the ability of rainfall to cause soil loss under different conditions and it is one of the six factors in the Universal Soil Loss Equation (USLE) (Wischmeier and Smith, 1958a) and the Revised Universal Soil Loss Equation (RUSLE) (Renard et al., 1997). Both methods are employed to predict soil erosion (Kinnell, 1973; Sharpley and Williams, 1990; Wang and Jiao, 1996; Yu and Rosewell, 1996; Oduro-
Afriyie, 1996; Mikhailova et al., 1997; Yu, 1998; Hu et al., 2000; Loureiro and Coutinho, 2001; Yu et al., 2001).

Unfortunately, rainfall erosivity studies in Nigeria have received very little attention especially as regards their spatial patterns. The need for quantification of rainfall erosivity is therefore imperative. The focus of this study is to evaluate the spatial patterns of rainfall erosivity over southeastern Nigeria.

\section{Study Area}

Southeastern Nigeria is located between latitudes $4^{\circ} 10^{\prime} \mathrm{N}$ and $70^{\circ} 08^{\prime} \mathrm{N}$, and longitudes $5^{\circ} 30^{\prime} \mathrm{E}$ and $9^{\circ} 27^{\prime} \mathrm{E}$. It is bounded to the south, east and west by the Atlantic Ocean, Republic of Cameroon and Delta State respectively and to the North by the middle belt states of Kogi and Benue. The region has a land area of about 75,488 square kilometers (Ofomata, 1975). Southeastern Nigeria is made up of nine states (ie. Anambra, Enugu, Ebonyi, Abia, Imo, Rivers, Bayelsa, Cross-River and Akwa Ibom). For the purpose of this study the focus is on only the states with climatic data (they serve as climatic stations. These are Anambra, Enugu, Owerri, Port-Harcourt, Calabar, Akwa- Ibom States (Fig 1).

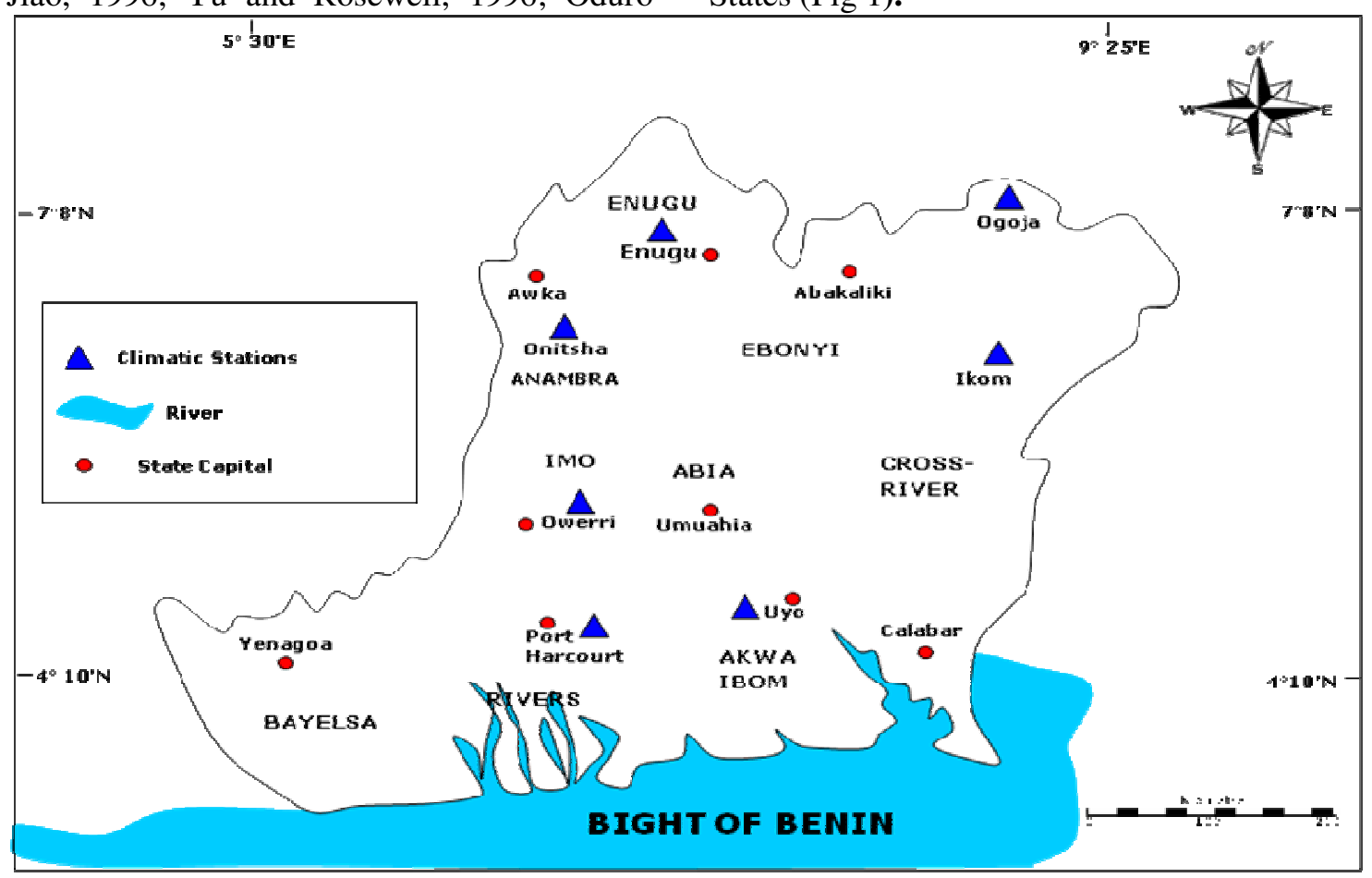

FIG.1 Southeastern Nigeria showing climatic stations 
The study area has a tropical climate with humidity and rainfall decreasing from the coast inland. The region is characterized by uniformly high temperature and a seasonal distribution of bimodal rainfall (Jungerius, 1964; Monanu, 1975a Anyadike, 2002). The mean daily maximum temperature is usually above $27^{\circ} \mathrm{C}$ all through the year whereas the daily minimum temperature does not usually fall below $18^{\circ} \mathrm{C}$ (Monanu, 1975b). The total annual rainfall increases from the northern frontier of the region to the southern frontier from a value of $1500 \mathrm{~mm}$ to a value exceeding $2500 \mathrm{~mm}$.

South-eastern Nigeria lies in the Lowland rainforest natural vegetation belt with evergreen trees in the south, and gradually gives way northward to rainfall-savannah forest characterized by trees interspersed with grass. The natural vegetation of the study area has been disturbed over the years through forest clearance and bush burning for agriculture (Ibeanu and Umeji, 2003). Generally, the soils of the study area were derived from shale and sandstone parent materials. These soils are generally deep, porous and acidic. Agricultural land use still is a major occupation for more than 60 percent of the populace of the study area.

\section{Methodology}

The basic approach employed in this study involved simulating the potential ability of rainfall to detach and transport soil materials using climatic data as guidelines. This method has been employed and adopted to African condition (Lal, 1976; Roose, 1977). Climatic data used for this study were collected for eight synoptic stations across the study area from the Nigeria Meteorological Agency, Lagos for the periods 1982-2005. These stations are Enugu, Owerri, Onitsha, Port Harcourt, Uyo, Ikom, Ogoja and Calabar.

The erosiveness of storms in the study area was determined as a function of rainfall kinetic energy using the model developed by Kowal and Kassam (1976). The choice of the model is based on the fact that the method was developed using tropical rainfall samples.

Besides, its development was based on direct measurements of rainfall kinetic energy with a piezoelectric sensor that can convert impact strain of a rainfall into an electrical signal within the sensing element The equation for computing Kinetic energy of rain is given as;

$\mathrm{K} . \mathrm{E}=(41.4 \mathrm{Ra}-120) \times 10^{3}$---------------equ 1

(Kowal and Kassam, 1976)

Where K.E is rainfall kinetic energy $\left(\mathrm{ergscm}^{-2}\right)$ and $\mathrm{Ra}$ is rainfall amount per storm $(\mathrm{mm})$. Equation (1) was converted to S.I units as suggested for factors in the Universal Soil Loss Equation USLE (Foster et al., 1981) from $\operatorname{ergscm}^{-2}$ to $\mathrm{MJha}^{-1}$ by multiplying by a factor of $1 \times 10^{-5}$.

The analysis of rain gauge chart to generate rainfall intensity date is extremely timeconsuming (Charreau 1969; C.T.F.T/HauteVolta 1974; Galabert and Millogo, 1973). In most cases such data is hardly adequate where there are available as the case with the study area. In an attempt to provide alternative methods for estimating erosivity factor in the records on rainfall intensity, several authors such as Charreau, (1972); Roose (1976); Delwaulle (1973); Galabert and Millogo (1973) have developed mathematical equations that permit the estimation of the rainfall erosivity index as a function of rainfall amount. In this study, the model developed by Roose (1976) for estimating values of rainfall erosivity from rainfall amounts for West African climates was adopted. The equation is given as

$\mathrm{R}=(0.0158 \mathrm{H} \mathrm{x} \mathrm{130})$ - 1.2 -----------------equ 2

Where $\mathrm{R}$ is the index of erosivity in $\mathrm{mmh}^{-1}$, $\mathrm{H}$ is rainfall amount $(\mathrm{mm})$ and $1_{30}$ is rainfall intensity in 30minutes. Rainfall erosivity values computed for our study area were compared with the Rainfall Aggressivity Index (RAI) developed by Fournier (1960) and modified by Arnoldus, (1980).

\section{Results and Discussion}

The seasonal patterns of rainfall erosivity (R) for Onitsha, Port- Harcourt, Owerri, Enugu, Uyo, Calabar, Ikom and Ogoja are presented as Figures 2- 9. The figures showed that rainfall erosivity $(\mathrm{R})$ indices over Southeastern Nigeria range from very low to very high erosivity according to Rainfall Aggressivity Index (RAI) 
developed by Fournier (1960) and modified by Arnoldus, (1980) Table 1.

Table 1: Rainfall Aggressivity Index (RAI)

\begin{tabular}{ll}
\hline Rainfall erosivity & Interpretation \\
\hline $0-60$ & very Low \\
$61-90$ & Low \\
$91-120$ & Moderate \\
$121-160$ & High \\
Above 160 & Very high
\end{tabular}

(Source: Modified from Arnoldus, 1980)

For Onitsha station, High (R) values were recorded in June, July, August and September with the (R) values ranging from $133.1 \mathrm{~mm}$ to $145.5 \mathrm{~mm}$. Moderate $(\mathrm{R})$ months were recorded in May and October $(109.5 \mathrm{~mm}$ and $95 \mathrm{~mm}$ respectively, while low erosivity was obtained for April. Very low (R) values were obtained from November to March. For the PortHarcourt station, Very high (R) of $183 \mathrm{~mm}$ and $175.9 \mathrm{~mm}$ were recorded in July and September. May, June and August had values ranging from $135.6 \mathrm{~mm}$ to $151.5 \mathrm{~mm}$ indicating high (R). Very low (R) was calculated for the month of March $(58.6 \mathrm{~mm})$, while the month of April with (R) of $69.9 \mathrm{~mm}$ was low. It is noteworthy that moderate( $\mathrm{R})$ was not obtained for this station (Fig 3).

For the Owerri station, very high(R) were recorded between June and September (171.6mm (June), 177.7mm (July), 178.5mm (August) and $184.5 \mathrm{~mm}$ (September) respectively. High $(\mathrm{R})$ were recorded in May $(132.7 \mathrm{~mm})$, while moderate $(\mathrm{R})$ occurred in two months- April $(91.8 \mathrm{~mm})$ and October $(115.1 \mathrm{~mm})$. Very $\operatorname{low}(\mathrm{R})$ occurred in four months (November to March). Periods of low erosivity in this station was observed Fig 4.

Enugu station recorded High (R) from June (125.6mm) through to September $(134.3 \mathrm{~mm})$. Moderate(R) occurred in April, May and October with values of $79.4 \mathrm{~mm}, 115.2 \mathrm{~mm}$ and $95.4 \mathrm{~mm}$ respectively. Occurrence of very high erosivity value was not observed in any of the months in Enugu station. As with Onitsha station, Enugu station recorded five months of very low erosivity from November to March (Fig.5).

In Uyo station, between July and September very high $(\mathrm{R})$ values were observed for July (177.6mm) and $161.4 \mathrm{~mm}$ for September. High (R) were observed in May, June and August with(R) of $129.6 \mathrm{~mm}$, $136.9 \mathrm{~mm}$ and $155.3 \mathrm{~mm}$ respectively. October is the only month in Uyo with moderate (R) of $120 \mathrm{~mm}$. Low $(\mathrm{R})$ values were recorded in March $(66.9 \mathrm{~mm})$, April $(94.7 \mathrm{~mm})$, while very low(R) occurred between November and February. The sudden decline in (R) in August is may be attributable to the effect of the Little Dry Season (LDS) which is common with West African Rainfall (Fig. 6).

Calabar station had very high $(\mathrm{R})$ ranging from $192.4 \mathrm{~mm}$ to $227.1 \mathrm{~mm}$, from June to September. In the months of May and October high $(\mathrm{R})$ were recorded, while the month of moderate (R) was April (119.5mm). March $(88.2 \mathrm{~mm})$ and November $(75.2 \mathrm{~mm})$ had low $(\mathrm{R})$, while December to February had very low(R) (Fig. 7).

In Ikom station, it was observed that months of very low (R) rainfall erosivity spanned from November to March while April $(86.4 \mathrm{~mm})$ and May $(118.5 \mathrm{~mm})$ recorded low (R) values. The months of June, July and October are the months in this station in which erosivity values were high, with $\mathrm{R}$ values of $155.6 \mathrm{~mm}, 150.7$ and $141.5 \mathrm{~mm}$ respectively. Very high (R) erosivity values were also recorded for this station between the months of August (174.5mm) and September (162.9mm) (Fig 8).

In Fig 9 depicting Ogoja station, it was observed that September is the only month with very high erosivity value of $162.1 \mathrm{~mm}$. Generally, high erosivity values were recorded for the months of June (130.2mm), July $(129.4 \mathrm{~mm})$ and August $(136.5 \mathrm{~mm})$, while moderate $(\mathrm{R})$ were observed in the months of October and May. Very low (R) occurred in the months of November to March.

The mean monthly distributions of the kinetic energy (which represents the energy of rainfall to induce the initial removal of soil material) at different locations in the study area are presented as table 2. From the table, it was observed that rains were erosive between April to October for Onitsha, Port-Harcourt, Owerri, Enugu and Ikom stations. In Ogoja, erosive rainfall was observed to begin in the month of May with a Kinetic energy value of $93.7 \mathrm{MJha}^{-1}$. 
Erosive rains in Calabar were observed to begin in March to Novermber. On annual basis, highest erosive rains were recorded in Calabar with rainfall Kinetic energy of $1184.4 \mathrm{MJha}^{-1}$. This was followed by Owerri (962.8 $\mathrm{MJha}^{-1}$ ), Port-Harcourt (928.4 MJha $\left.^{-1}\right)$, Uyo (910.3 $\mathrm{MJha}^{-1}$ ) and Ikom (893.9 $\left.\mathrm{MJha}^{-1}\right)$. Enugu recorded the lowest annual erosive rainfall of 696.9 $\mathrm{MJha}^{-1}$. This may be attributed to the effect of the gradual decline in rainfall amount from the southern part of the study area to the north. Critical months in terms of aggressiveness of rains in the study area is of the order, June - September (Onitsha), MayOctober (Port-Harcourt), MaySeptember(Owerri), June-Sept(Enugu), MaySeptember (Uyo), May-October (Calabar), June-October (Ikom), and June- September (Ogoja). These results suggest that very severe erosion-causing rains occur in the middle of the rainy season in the study area. Calabar, PortHarcourt and Owerri which are near the coast recorded more erosive storms than locations away from the coast (Table 2).

The spatial pattern of mean annual rainfall erosivity (R) shown as Figure 10 depicts very high(R) in all the stations. From the figure, the study area has been grouped on the basis of rainfall erosivity. The southwestern part of the area which comprise Port-Hacourt and Owerri stations has a mean erosivity index ranging between $1071-1290 \mathrm{~mm}$. Enugu, Onitsha and Ogoja stations which constitute the northern part recorded an average erosivity index between $0-850 \mathrm{~mm}$. The southeastern part is made up of Calabar, Uyo and Ikom stations. Within this region, marked variation in erosivity was observed. Uyo and Ikom stations recorded a mean erosivity range values of $851 \mathrm{~mm}-1090 \mathrm{~mm}$ while calabar with erosivity value of between $1291 \mathrm{~mm}$ and $1510 \mathrm{~mm}$ recorded the highest erosivity value in the study area. This division reflects the diverse human and physical factors operative in the region.

To ascertain the extent to which the kinetic energy of the rains observed for the various stations can erode soil material, a deterministic relationship between rainfall erosivity and Kinetic energy of rainfall was calculated and this is presented as Table 3. The ability of the kinetic energy of the rains to induce erosion yielded positive values suggesting that erosive rains contribute significantly to the detachment of soil in the area. The coefficient of determination which expresses the percentage variation in the value of erosivity $(R)$ that can be explained by change in rainfall amounts (predictor) was high for all the stations. This supports the fact that rainfall is a major erosive/soil detachment factor in the erosional process of Southeastern Nigeria.

\section{Conclusion and Recommendations}

The rainfall erosivity of a tropical rain forest region has been investigated. The study established the erosivity index for southeastern Nigeria vis-a-viz Onitsha, Port-Harcourt, Owerri, Enugu, Uyo, Calabar, Ikom and Ogoja climatic stations to range from 0 -183 (i.e. from very low to very high erosivity). The very low erosivity $(0-60 \mathrm{~mm})$ occurred in all states generally from November to February coinciding with the dry season months in southeastern Nigeria. This also is indicative of the major erosive role played by the impact of rain drop. The high erosivity indices were noted for rainy season peak periods of June and September. The mean monthly distribution of the kinetic energy of storms at all the stations was observed to erosive between April to October, thus conforming with the erosivity Index pattern observed. This also suggests that very severe erosion-causing rains are associated with the rainy seasons in Southeastern Nigeria. Marked spatial variation in rainfall erosivity was observed in the study area with Calabar recording the highest erosivity value of $1368.4 \mathrm{~mm}$ and Enugu recording the lowest erosivity of $811.26 \mathrm{~mm}$. A gradual rise in rainfall erosivity is noted in the study area peaking in 1994 with a geneal decline from 1998. The ability of the kinetic energy of the rains to induce erosion yielded positive values that suggest that under disturbed conditions the rains will contribute significantly to the detachment of soil material in the study area hence enhancing accelerated erosion.

The fact that Calabar Owerri and PortHarcourt recorded the highest erosive storms 
with the more month of very high erosivity index portrays the potential ecological crisis in these areas with increase in rainfall amounts and further disturbance of land cover. There is need for monitoring of hydrologic regime and climate -related factors in the region as well as define areas most vulnerable to erosion. Land use management in relation to soil vulnerability is highly necessary.

\section{References}

Ahn, P.M. (1970): West Africa Soils. Oxford: University Press, London.

Arnoldus H.M. 1980. An aproximation of the rainfall factor in the Universal Soil Loss Equation. En: De Boodt M., and Gabriels D. (eds) Assessment of erosion. John Wiley and Sons, Inc. Chichester, West Sussex, UK. 127 132.

Angulo-Martinez, M., Lopez-Vicente, M., Vicente-Serrano, S.M., Begueria, S. (2009): Mapping rainfall erosivity at a regional scale: a comparison of interpolation methods in the Ebro Basin (NE Spain). Hydrol. Earth Syst. Sci. Discuss. 6, 417- 453

Asadi, H., Rouhipour, H., Rafahi, H. Gh. and Ghadiri, H. (2008). Testing a Mechanistic Soil Erosion Model for Three Selected Soil Types from Iran. J. Agr. Sci. Tech., 10(1): 79-91.

Charreau, C. 1972. Probtemes pos'es par L' utilization agricole des sols tropicaux par les cultures annuelles. Coll. IITA - IRAT, Ibadan, Nigeria.

Charreau, C. 1969. Influence des techniques culturales sur le develop pement $d u$ missellement ret de 1 'érosion en Casamance, International du Génie Rural. C.N.R.A., Bambey. 13 pp.

C.T.F.T./Haute-Volta. 1974. Rapport de synthsse 1973. C.T.F.T.1 . Ministère de l'Agriculture de Haute-Volta. Onagadougou. pp 56

Delwaulle J.C 1973): Rsultats de six ans d'

Observations sur L' EROSION AU Niger. Bois et Forets Tropiques 150: 15-36

Diamond, J. (2005) Collapse: How Societies Choose to Succeed or Fail. Viking Press, New York, 592 PP.
Diodata N and Bellocchi G (2010): MedREM, a rainfall erosivity model for the Mediterranean region, Journal of Hydrology 387, 119-127

Easterling, D.R., Evans, J.L., Groisman, Ya, P., Karl, T.R., Kunkel, K.E., Ambenje, P., (2000): Observed variability and trends in extreme climate events: a brief review. Bull. Am. Meteor. Soc. 81, 417-425.

Elwell H.A and Stocking M.A (1974): Rainfall parameters and a cover model to predict runoff and Soil loss from grazing land in the arahodesia Sandvels, Proc. Grassland Soc. Afri Vol 9, 157-167pp

Fournier F. (1960) Climat et érosion. Ed. Presses Universitarires de France. Paris.

FAO (1987), "Soil and Water Conservation in Semi-arid Areas", Soil Bulletin 57:21-98

Galabert, J. , and E. Millogo. 1973. Indice d'érosion de la Pluie en Haute-Volta C.T.F.T., Ouagadougou. 34 pp.

Garcia-Oliva, F., Maass, J.M., Galicia, L (1995): Rainstorm analysis and rainfall erosivity of a seasonal tropical region with a strong cyclonic influence on the Pacific Coast of Mexico. J. Appl. Meteor. 34, 2491-2498.

Hu, Q., Clark, J. G., Jung, P. and Lee, B. 2000.

Rainfall Erosivity in the Republic of Korea. $J$.

Soil Water Conserv., 55 (2): 115- 120.

Ibeanu A.M and Umeji O.P (2003): Aspects of the Palaeocology of Okigwe Cuesta, eastern Nigeria. West African J . Archaeology 31(1): 17-30

Jeje, L.K. and Agu, A.N. (1990), "Run-off from Bounded Plots in Alakowe in South Western Nigeria", Applied Geography, 10:6374.

Jungerius P. D (1964): The Soil of eastern Nigeria. Publ. serive geologique du Luxemborg XIV: $185-198$

Kowal J.M and Kassam A.H (1973): A simple device for analyzing the energy load intensity of rainstorms. Agric Met. 12: 271-280 Kinnell, P. I. A. (1973): Runoff Effects on the Efficiency of Raindrop Kinetic Energy in Sheet Erosion. Soil Sci. Soc. Am. J., Vol 5 399-405

Lal, R (1976): Soil erosion problems on an alfisol in Western Nigeria and their control, IITA Monograph No. 1 Ibadan Nigeria, 160pp 
Ludwig, J. A. and Tgway, D. J. 2000. Viewing Rangelands as Landscape Systems In: "Rangeland Desertification". (Eds.): Arnalds, O. and Archer, S., Kluwer Academic Publishers, Dordrecht, PP. 39-52.

Loureiro, N. S. and Coutinho, M. A. 2001. A New Procedure to Estimate the RUSLE EI30 Index, Based on Monthly Rainfall Data and Applied to the Algarve Region Port. J. Hydrol., 250: $12-18$

Ludwig, J. A., Eager, R. W., Liedloff, A. C., Bastin, G. N. and Chewings, V. H. 2006. A New Landscape Leakiness Index Based on Remotely Sensed Ground-cover Data. Ecol. Indicators, 6: 327-336.

Mananu P.C (1975a): Rainfall in G.E.K Ofomata (Ed.) Nigeria in Maps: Eastern States. Ethiope Publ. Benin, Nigerria. Pp. 2526

Mananu P.C (1975b); Temperature and sunshine in G.E.K Ofomata (Ed.) Nigeria in Maps: Eastern States. Ethiope Publ. Benin, Nigerria. Pp. 16-18

Mikhailova, E. A., Bryant, R. B., Schwager, S. J. and Smith, S. D. (1997). Predicting Rainfall Erosivity in Honduras. Soil Sci. Soc. Am. J., 61(1): 273-279.

Nearing, M.A., Pruski, F.F., O’Neal, M.R., (2004). Expected climate change impacts on soil erosion rates: a review. J. Soil Water

Conserv. 59, 43-50.

Oduro-Afriyie, K. 1996. Rainfall Erosivity Map for Ghana. Geoderma, 74: 161-166

Ofomata G.E.K (1965): Factors of soil erosion in the Enugu area of Nigeria. Nigeria Geogr J vol.8 pp 45-59

Ofomata G.E.K (1975): Soils In G.E.K Ofomata (Ed), Nigeria in Maps: Eastern States. Ethiope Publ. House, Benin, Nigera. Pp 41-42

Ofomata G.E.K (1998): Land Degradation in Southeastern Nigeria. Journal of Applied Social Sciences, vol 1 no 1 pp 5-14

Ologe K.O (1972): Gullies in the Zaria area: a preliminary study of headscape recession. Savanna 1 pp 55-66

Olson, G.W. (1982), “Opportunities for Improving Land Uses through Soil Survey Interpretations Perspectives", in Prinya, N. (ed.), First International Symposium on Soils, geology and land Forms/Impact on Land Use Planning in Developing Countries, Bangkok, Thailand. Opie, J. 2000. Ogallala: Water for a dry land. University of Nebraska Press, Lincoln. Pierson, F.B. 2000. Erosion Models: Use and Misuse on Rangelands. In: "Rangeland Desertification". (Eds.): Arnalds, O. and Archer, S., Kluwer Academic Publishers, Dordrecht, PP. 67-76. Oyegun, R.O. (1980), 'The Effects of Tropical rainfall on Sediment Yield from different land use surfaces in Sub-urban Ibadan". A Ph.D. Thesis submitted to the Department of Geography, University of Ibadan, pp. 21-151.

D.C. (1997): Predicting soil erosion by water: A guide to conservation planning with the revised universal soil loss equation (RUSLE). USDA Agriculture Handbook No. 703, United States Department of Agriculture (USDA), Agricultural Research Service, Washington

Roose E.T (1975): Application de L' equation de prevision de L' erosion de Wischmeir et smith en Afrique de L' Quest. Coll. I.I.T.A Ibadan Nigeria 22pp

Roose E.J (1976): Use of the Universal soil Loss equation to predict erosion in West Africa: Soil Erosion: Prediction and Control : Soil conservation society of America Ankeny, Lowa

Roose, E., (1977): Application of the universal soil loss equation in West Africa. In: Greenland, D.J., Lal, R. (Eds.), Soil Conservation and Management in the Humid Tropics. John Wiley and Sons, Chichester, United Kingdom, pp. 177-188

Sauerborn, P., Klein, A., Botschek, J., Skowronek, A., (1999) Future rainfall erosivity derived from large-scale climate modelsmethods and scenarios for a humid region. Geoderma 93, 269-276.

Sharpley, A. N. and Williams, J. R. (1990): EPIC-Erosion/productivity Impact Calculator. U.S. Department of Agriculture Technical Bulletin, 1768

Schutt, B., Schwanghart, W., Ducke, K., Fritzenwenger, G., Husdler, J., Lange, J., Lippitz, A., Lowenhertz, R., Lubnina, T., Marquardt, N., Protze, N., Schimpf, S., Schobrabnski, F., (2007): Field study "Landscape sensitivity. Landscape sensitivity 
in the Uguii Nuur catchment, Mongolia, with a special focus on soil erosion. Freie Universitat Berlin, Germany

Wang, W. Z. and Jiao, J. Y. (1996) Quantitative Evaluation on Factors Influencing Soil Erosion in China. J. Soil Water Conserv., China, 16(5):1-20. (In Chinese Abstract in English)

Wischmeier W.H and Smith D.D (1958a): Rainfall energy and its relationship to soil loss. Trans. Am Geophy. Unoin 39: 285-291

Wischmeier, W. H. and Smith, D. D. (1958b): Rainfall Energy and its Relationship to Soil Loss. Trans. Am. Geophysics Union, 39: 285-291

Young, A. (1972), Slopes, Geomorphology Text 3, Edinburgh: Oliver \& Boyd, pp. 25-72.
Yu, B. (1998): Rainfall Erosivity and Its Estimation for Australia's Tropics. Aust. J. Soil Res., 36 (1): 143-165.

Yu, B., Hashim, G. M. and Eusof, Z. 2001. Estimating the $\mathrm{R}$ Factor with Limited Rainfall Data, A Case Study from Peninsular Malaysia. J. Soil Water Conserv., 56 (2): 101-105.

$\mathrm{Yu}$, B. and Rosewell, C. J. (1996): An Assessment of a Daily Rainfall Erosivity Model for New South Wales. Aust. J. Soil Res., 34: 139-152

Zachar, D., (1982): Erosion factors and conditions governing soil erosion and erosion processes. In: Zachar, D. (Ed.), Soil Erosion. Elsevier Scientific Publishing Company, Amsterdam, The Netherlands, pp. 205-388

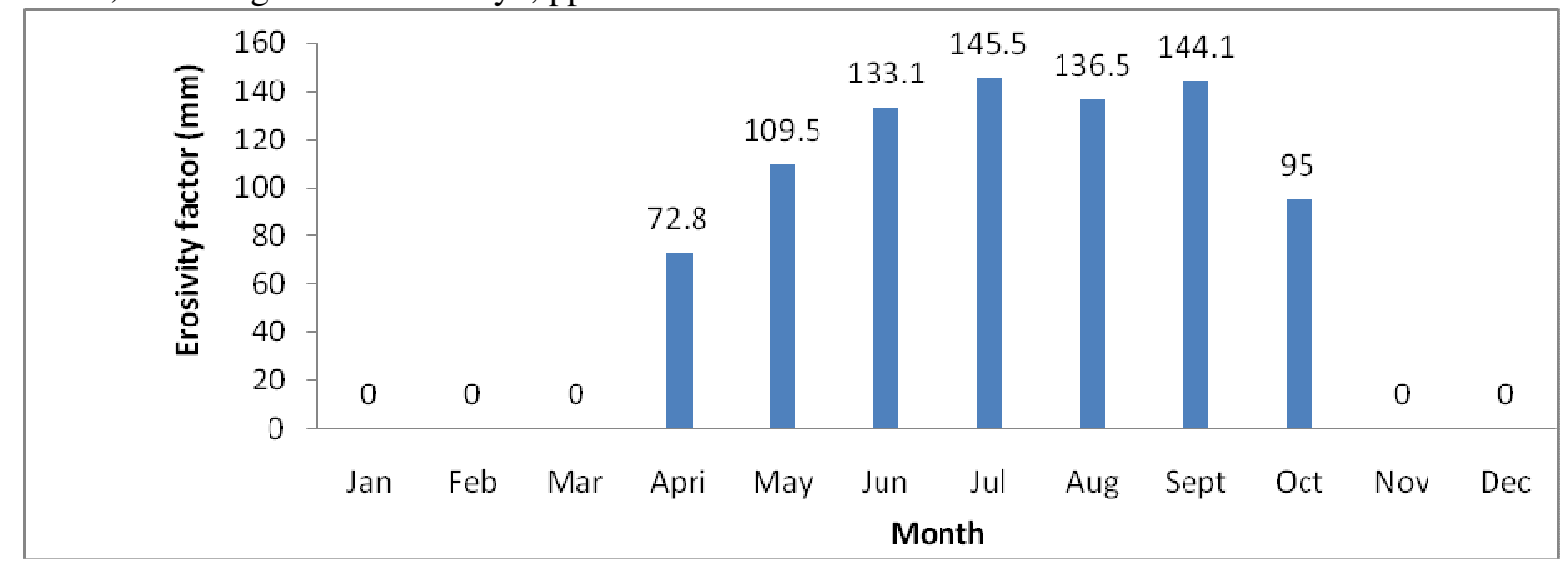

Fig.2: Rainfall erosivity Index pattern in Onitsha

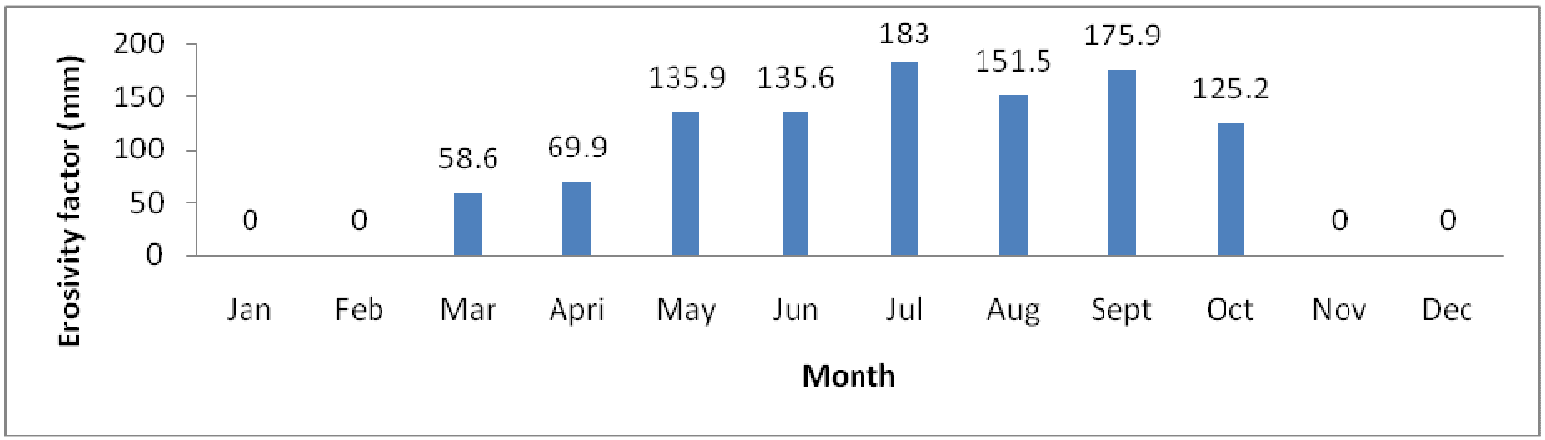

Fig 3: Rainfall erosivity Index pattern in Port-Harcout 


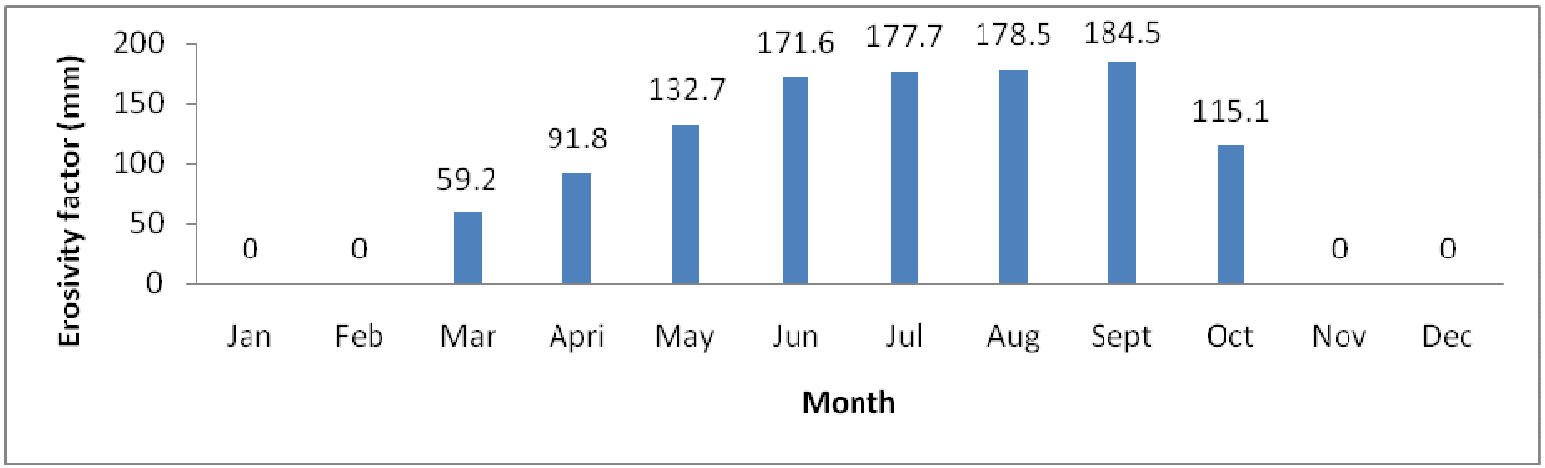

Fig 4: Rainfall erosivity Index pattern in Owerri

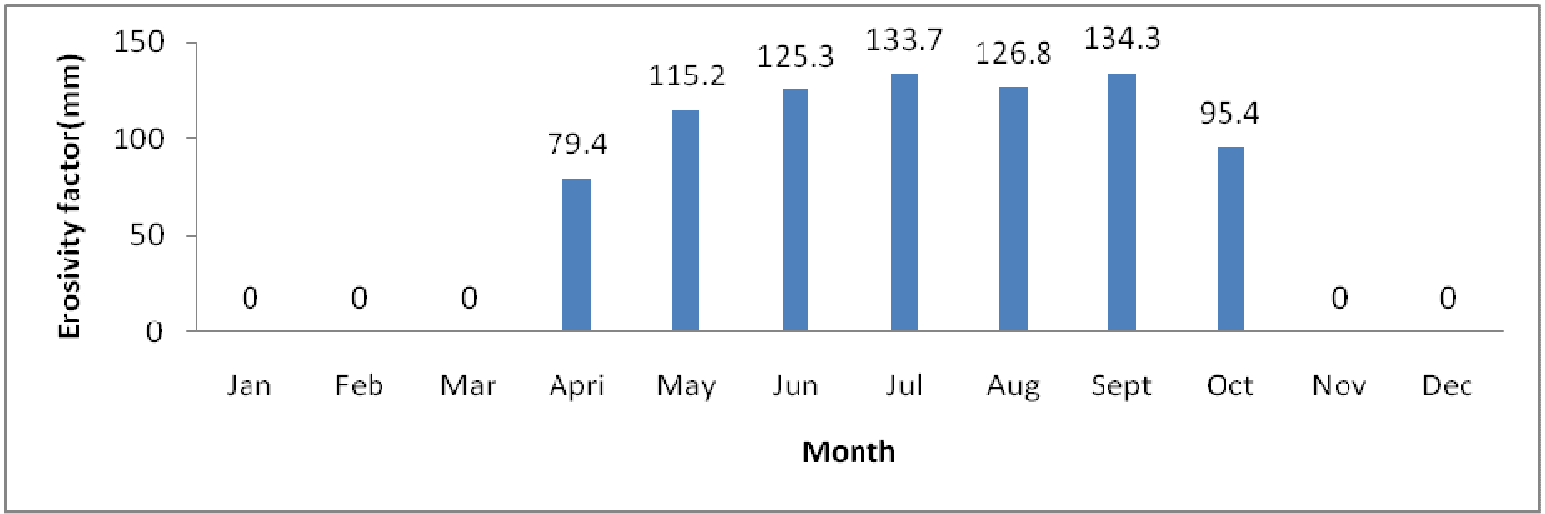

Fig 5: Rainfall erosivity Index pattern in Enugu

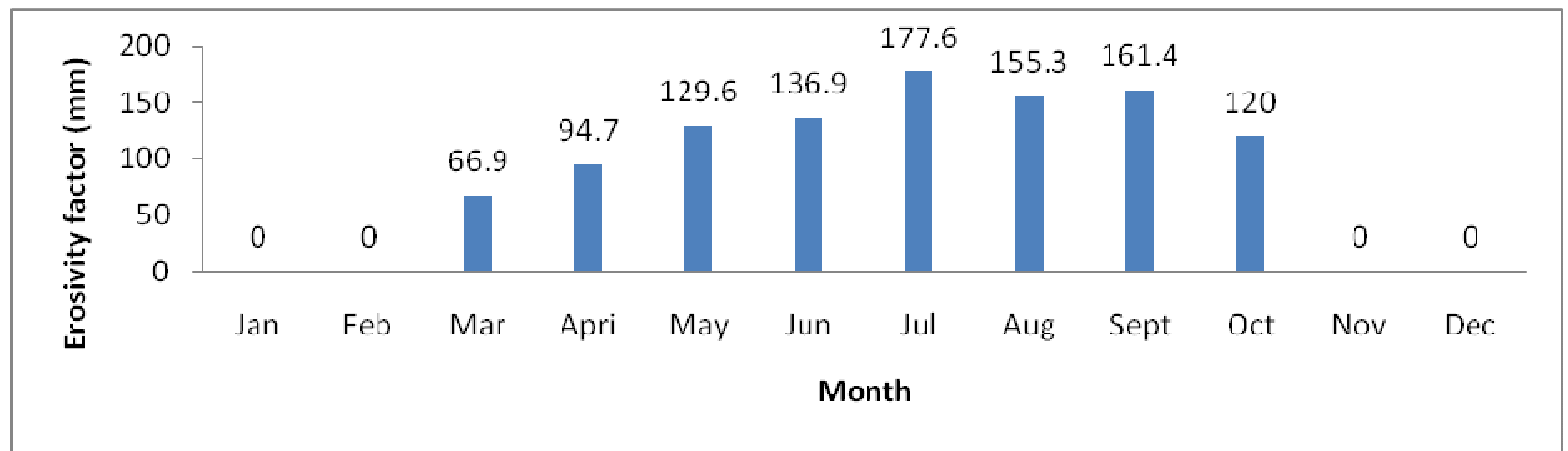

Fig 6: Rainfall erosivity Index pattern in Uyo

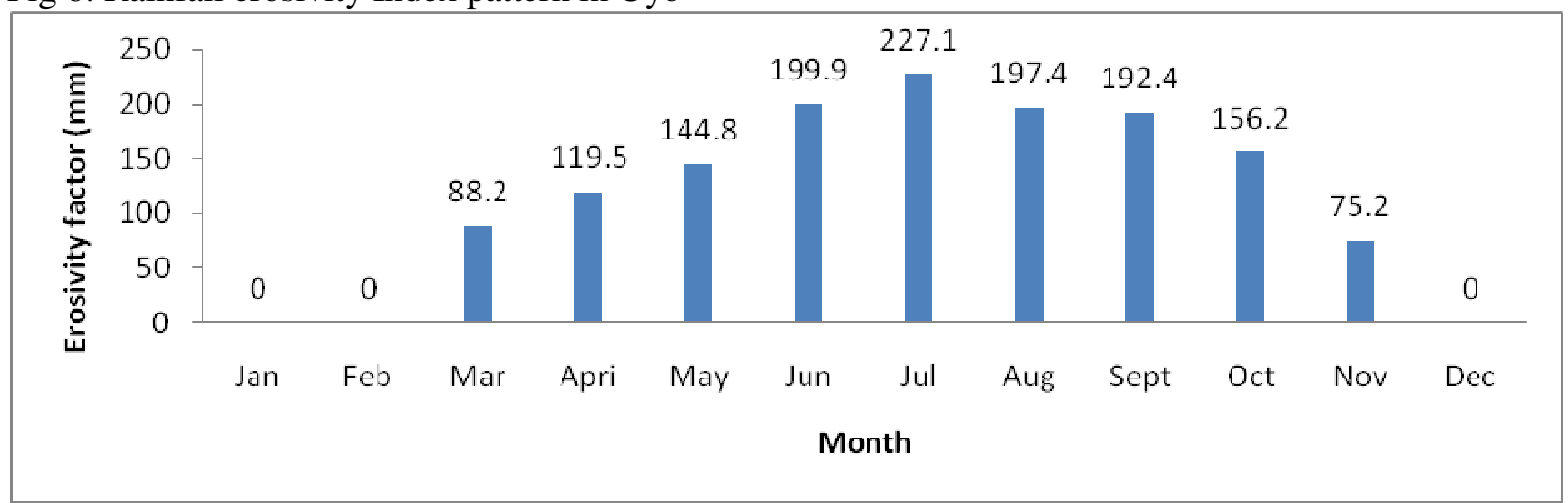

Fig 7: Rainfall erosivity Index pattern in Calabar 
Ethiopian Journal of Environmental Studies and Management EJESM Vol. 5 No. 22012

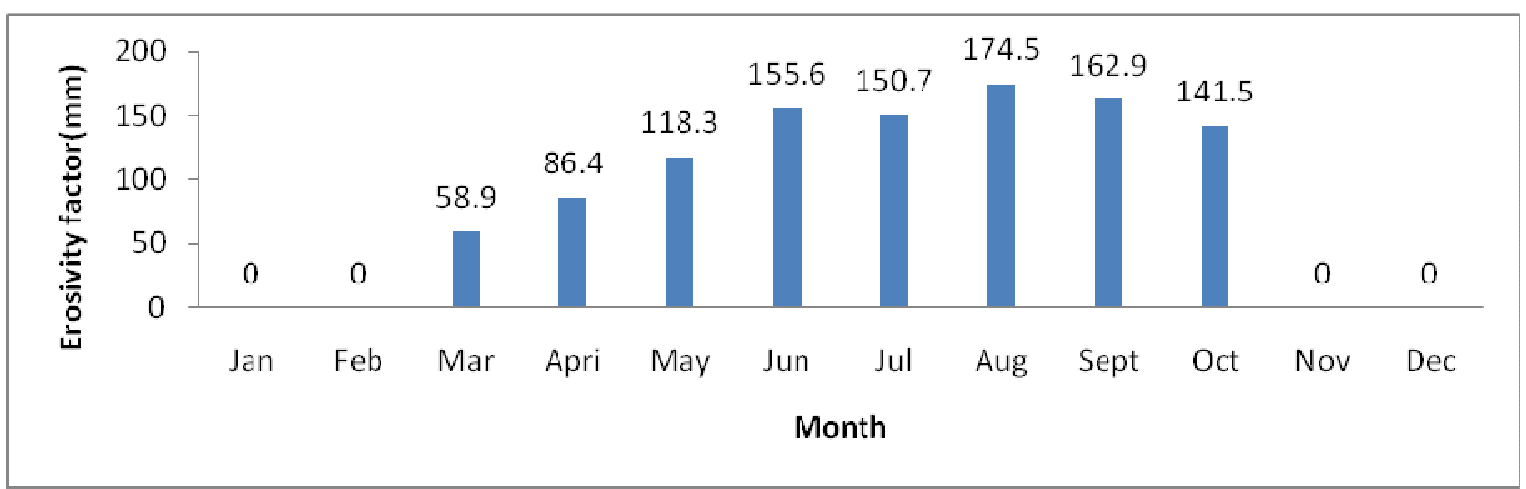

Fig 8: Rainfall erosivity Index pattern in Ikom

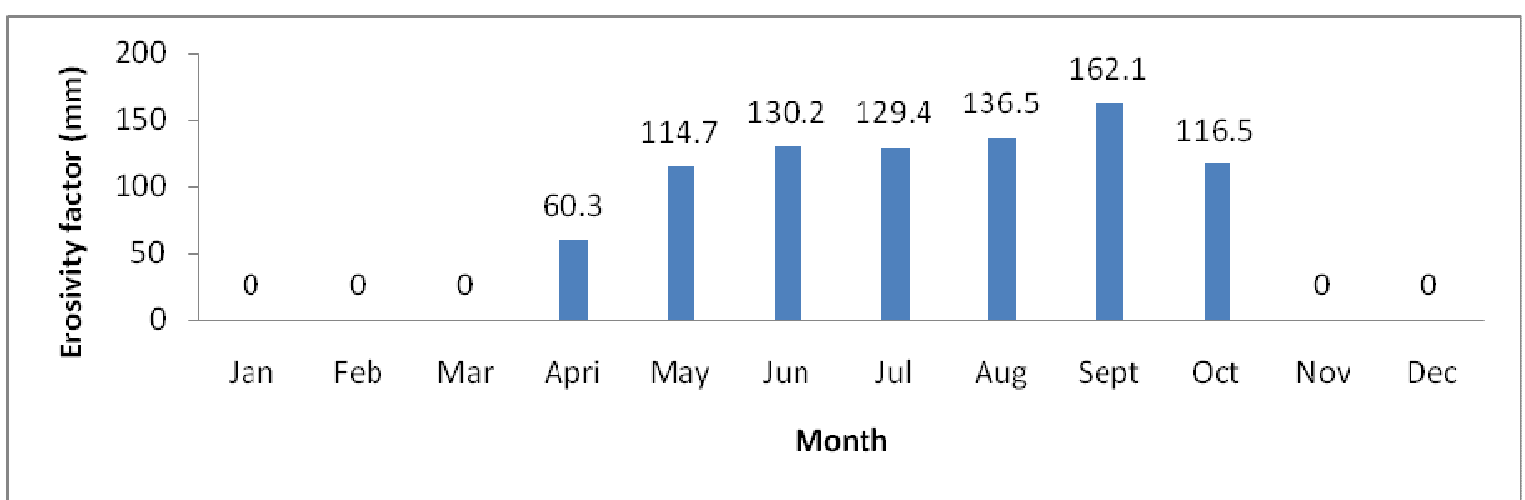

Fig 9: Rainfall erosivity Index pattern in Ogoja

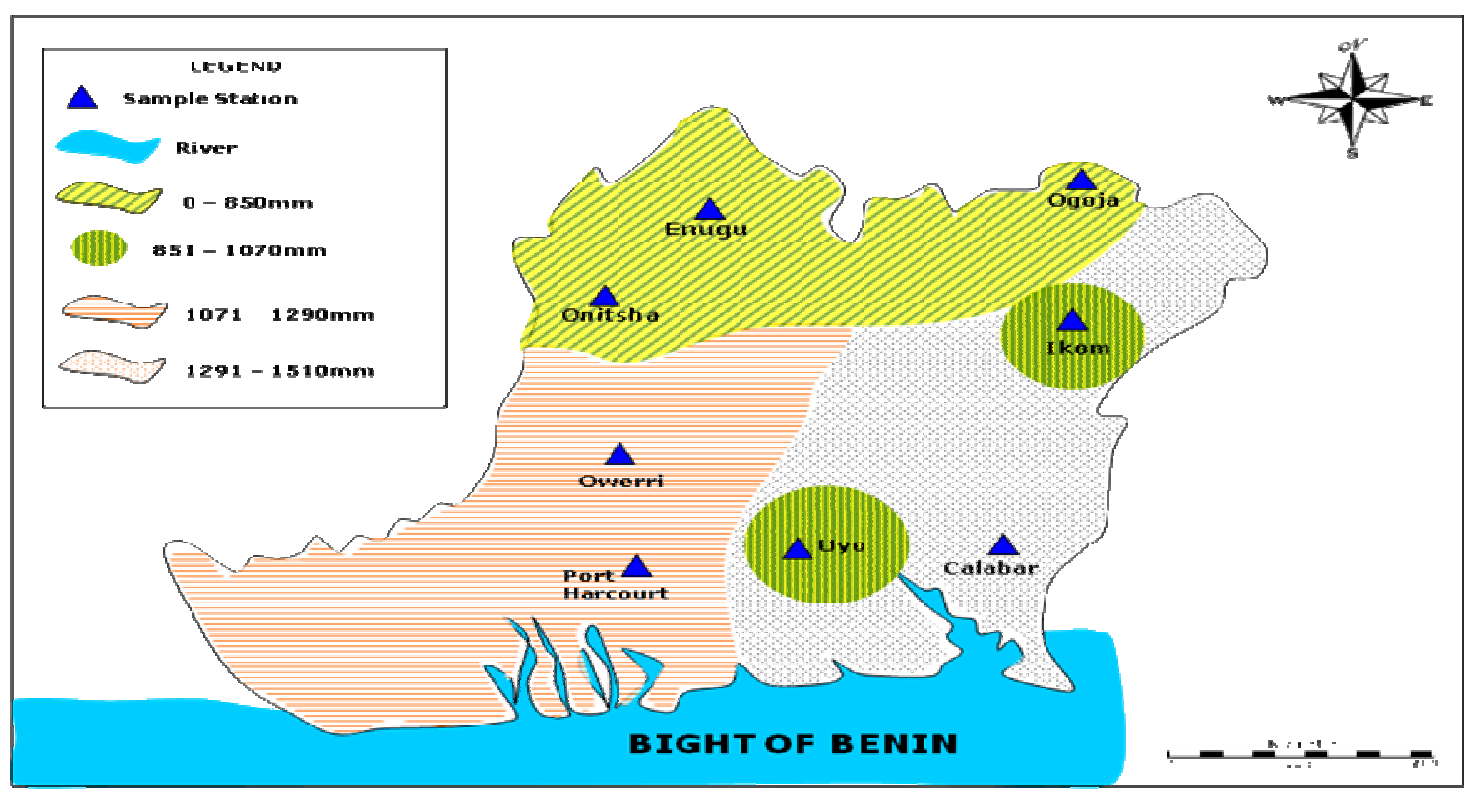

FIG. 10: Spatial pattern of mean Annual Rainfall Erosivity over southeastern Nigeria 
Table 2 Computed Average Kinetic energy of rainfall $\left(\mathrm{MJha}^{-1}\right)$ at different locations in Southeastern Nigeria (1982-2005)

\begin{tabular}{lrrrrrrrr}
\hline Month & Onitsha & \multicolumn{1}{l}{$\begin{array}{l}\text { Port- } \\
\text { Harcourt }\end{array}$} & \multicolumn{1}{l}{ Owerri } & \multicolumn{1}{l}{ Enugu } & Uyo & Cal & Ikom & Ogoja \\
\hline Jan & 2.94 & 11.7 & 12.4 & 1.6 & 9.4 & 10.1 & 2.7 & 3.1 \\
Feb & 4.7 & 22.6 & 13.8 & 3.6 & 13.2 & 12.5 & 10.8 & 3.1 \\
Mar & 30.1 & 47.4 & 47.8 & 22.4 & 54.2 & 71.8 & 48.7 & 21.9 \\
Apri & 58.6 & 56.7 & 74.9 & 64.5 & 77.2 & 97.7 & 70.3 & 48.7 \\
May & 89.4 & 111.4 & 108.6 & 94.1 & 106.1 & 118.6 & 96.8 & 93.7 \\
Jun & 108.9 & 111.1 & 140.8 & 102.5 & 112.1 & 164.4 & 127.6 & 106.6 \\
Jul & 119.3 & 150.3 & 145.9 & 109.5 & 145.8 & 186.8 & 123.5 & 105.9 \\
Aug & 11.9 & 124.2 & 146.6 & 103.7 & 127.4 & 162.2 & 143.2 & 111.8 \\
Sept & 118.1 & 144.4 & 151.5 & 110 & 132.4 & 158.1 & 133.7 & 133 \\
Oct & 77.5 & 102.5 & 94.1 & 77.7 & 98.2 & 128.1 & 115.9 & 95.3 \\
Nov & 7.6 & 34.7 & 20.2 & 7.3 & 30.2 & 61 & 16.9 & 7.5 \\
Dec & 1.3 & 11.4 & 6.2 & 0 & 4.1 & 13.1 & 3.8 & 1.7 \\
Annual & 730.34 & 928.4 & 962.8 & 696.9 & 910.3 & 1184.4 & 893.9 & 732.3 \\
Mean & & & & & & & & \\
\hline
\end{tabular}

Table 3 Deterministic relationship between Kinetic energy of rainfall $\left(\mathrm{MJha}^{-1}\right)$ and rainfall erosivity ( $\mathrm{mm})$

\begin{tabular}{lllll}
\hline $\begin{array}{l}\text { Climatic } \\
\text { Station }\end{array}$ & $\begin{array}{l}\mathrm{R} \text { (correlation } \\
\text { coefficient) }\end{array}$ & $\begin{array}{l}\mathrm{R}^{2} \text { (Coefficient of } \\
\text { determination) }\end{array}$ & Adjusted R & $\begin{array}{l}\text { Std. Error of the } \\
\text { estimate }\end{array}$ \\
\hline Onitsha & 0.989 & 0.977 & 0.975 & 10.2 \\
Port-Harcourt & 0.989 & 0.978 & 0.976 & 11.37 \\
Owerri & 0.997 & 0.994 & 0.993 & 6.3 \\
Enugu & 0.993 & 0.986 & 0.985 & 7.6 \\
Uyo & 0.992 & 0.983 & 0.982 & 9.5 \\
Calabar & 0.999 & 0.997 & 0.997 & 4.5 \\
Ikom & 0.997 & 0.995 & 0.994 & 5.4 \\
Ogoja & 0.995 & 0.989 & 0.988 & 7.2 \\
\hline
\end{tabular}

